\begin{tabular}{lr}
\hline PRACE NAUKOWE UNIWERSYTETU EKONOMICZNEGO WE WROCLAWIU \\
RESEARCH PAPERS OF WROCLAW UNIVERSITY OF ECONOMICS & nr 472 • 2017 \\
\hline Dylematy zarządzania kosztami i dokonaniami & ISSN 1899-3192 \\
& e-ISSN 2392-0041
\end{tabular}

\author{
Bogdan Nogalski \\ Wyższa Szkoła Bankowa w Gdańsku \\ e-mail: bogdan.nogalski@ug.edu.pl
}

Przemysław Niewiadomski

Politechnika Poznańska

e-mail: niewiadomski@zpcz.pl
KOSZTY IMPLEMENTACJI JAKO BARIERA
INNOWACJI PRODUKTOWYCH
W ŚWIETLE STRATEGII DYFERENCJACJI - STUDIUM PRZYPADKU*

\title{
COSTS OF IMPLEMENTATION AS A BARRIER TO PRODUCT INNOVATION IN THE LIGHT OF DIFFERENTIATION STRATEGY - CASE STUDY
}

DOI: 10.15611/pn.2017.472.27

JEL Classification: O31, O32, O33, L23, L61

\begin{abstract}
Streszczenie: Zasadniczym celem niniejszej pracy jest próba przedstawienia ponoszonych przez wytwórcę kosztów implementacji nowego wyrobu jako bariery innowacji produktowych. Osiągnięcie tak postawionego celu jest możliwe poprzez analizę wybranego przypadku implementacji, który potwierdza, że związane z nią koszty - wskutek niewielkiej serii produkcji - mogą implikować sytuację, w której następuje ograniczenie zysku lub nawet strata, co w perspektywie krótkoterminowej stanowi przesłankę o jej zaniechaniu. W ramach badań uzyskano także odpowiedź na pytanie: czy ilość implementowanych przez wytwórcę wyrobów jest pochodną - posiadanych przez niego - zdolności technologicznych odzwierciedlonych w możliwości pozyskania i wykorzystania nowej technologii wytwarzania?
\end{abstract}

Słowa kluczowe: koszty implementacji, elastyczność, strategia dyferencjacji, bariera implementacji.

Summary: The main aim of this paper is an attempt to present the costs of implementation of a new product incurred by the manufacturer as a barrier to product innovation. Achieving this objective is possible by analysing selected case of implementation, which confirms that the associated costs - as a result of a small series of production - may imply a situation in which the limitation of a profit, or even a loss occurs; in a short-term perspective constitutes

* Studium przypadku odniesiono do celowo wybranego przedsiębiorstwa związanego z produkcją części maszyn rolniczych. Wytwórcy tego sektora są obiektami - dotychczas prowadzonych przez autorów - badań, których wyniki prezentowano w odrębnych opracowaniach naukowych. 
a premise of failure of implementation. As part of the study, the answer to the following question was obtained: whether the amount of implemented products by the manufacturer is a derivative of its technological capabilities reflected in the possibility of gaining and using new manufacturing technology?

Keywords: costs of implementation, flexibility, differentiation strategy, implementation barrier.

Zysk jest zaptata, jaka otrzymujesz, kiedy wykorzystujesz okazję, jaka daje ci zmiana.

J. Schumpeter [www1]

\section{Wstęp}

Szybki postęp technologiczny sprawił, że innowacyjność stała się podstawowym czynnikiem determinującym pozycję konkurencyjną przedsiębiorstwa [Nowak, Wierzbiński 2010, s. 312]. Przewagę konkurencyjną - w wielu przypadkach - zdobywają te przedsiębiorstwa, które jako pierwsze potrafią zaimplementować nowy produkt ${ }^{1}$. Standardem rozwoju współczesnych przedsiębiorstw staje się zatem model innowacyjny polegający na dostarczaniu na rynek coraz bardziej atrakcyjnej oferty produktowej. W związku z powyższym przedsiębiorstwa powinny stale podnosić standardy produktowe jako wynik konsekwentnego poszerzania wiedzy w organizacji i wykorzystywania tej wiedzy w procesach implementacyjnych. Orientacja na nieustanne wprowadzanie innowacji produktowych, implikująca powiększanie i rozwijanie posiadanego portfela produktowego sprzyja jednocześnie podnoszeniu wartości samego przedsiębiorstwa.

Strategia dyferencjacji produktowej ${ }^{2}$ jest jak najbardziej aktualnym zagadnieniem zwłaszcza w odniesieniu do sektora mechanizacji rolnictwa ${ }^{3}$, tym bardziej że Ministerstwo Rolnictwa i Rozwoju Wsi przewiduje wspomaganie rozwoju gospodarczego obszarów wiejskich poprzez stworzenie efektywnej infrastruktury technicznej i społecznej. Poprawa i stabilizacja warunków ekonomicznych rolnictwa, zachowanie jak największej liczby gospodarstw rodzinnych i zapewnienie im rów-

\footnotetext{
1 Przy czym klienci - w większym niż dotychczas stopniu - zaczęli zwracać uwagę na jego oryginalność.

2 W niniejszym opracowaniu dyferencjację definiuje się jako posiadanie oferty rynkowej, która przynależąc do danej dziedziny działalności, odróżnia się od oferty standardowej w tej dziedzinie różnorodnością i dostępnością zaimplementowanych wyrobów, różnice te zaś rynek wyraźnie dostrzega.

3 Polskie rolnictwo jest specyficzne. Charakteryzuje się dużym zróżnicowaniem i rozwarstwieniem obszarowym gospodarstw w poszczególnych regionach. W województwach południowych (małopolskie, podkarpackie) średnia powierzchnia gospodarstw nie przekracza 5 ha, a województwa północne i zachodnie charakteryzują się średnią powierzchnią od 20 do ponad 30 hektarów. To zróżnicowanie powoduje, że gospodarstwa mają także zróżnicowane wyposażenie w środki techniczne, zarówno pod względem ilości, jak i jakości.
} 
nych warunków konkurencji implikuje zapotrzebowanie na zróżnicowane - zarówno pod względem jakościowym, ilościowym, jak i cenowym - wyroby.

Szacuje się zatem, że do 2020 r. przemiany produkcyjne i technologiczne będą zachodzić w około 500 tys. rozwojowych gospodarstw rodzinnych, a w około 100 tys. gospodarstw zostanie wprowadzona produkcja ekologiczna [Pawlak 2013, s. 90]. Podstawą modernizacji i rozwoju będą więc zmiany w wyposażeniu gospodarstw w środki trwałe, w tym w nowoczesne środki techniczne, niezbędne do wprowadzania nowych, wysokowydajnych i energooszczędnych technologii.

Dzięki dopłatom unijnym wiek i stopień zużycia maszyn i ciągników oraz związana z tym luka technologiczna, dzieląca polskie rolnictwo od rolnictwa przodujących krajów Europy Zachodniej, będzie minimalna. W perspektywie najbliższych lat wiele gospodarstw rolnych w Polsce nie będzie już musiało modernizować zużytego parku maszynowego. W związku z powyższym produkcja i sprzedaż większości znormalizowanych części i podzespołów systematycznie będzie spadać.

Nowe środki mechanizacji rolnictwa będą bardzo zróżnicowane. Ich kształty, wymiary, konfiguracja, wewnętrzna struktura itp. są projektowane i wytwarzane w ten sposób, aby optymalnie spełniać zakładane funkcje. Czynniki te wskazują na ogromne zróżnicowanie części zamiennych i podzespołów tych maszyn. Dodatkowo w województwach, gdzie rolnictwo jest gorzej wyposażone (mniejsze moce ciągników), zapotrzebowanie na części będzie inne niż w województwach o wyższym poziomie wyposażenia technicznego gospodarstw. Pojawia się popyt na części do dużych - jeszcze bardziej zaawansowanych technologicznie - zróżnicowanych maszyn.

W kontekście powyższego pożądaną cechą współczesnego wytwórcy - działającego w badanym sektorze - są częste implementacje nowych części i podzespołów. Wiąże się to $\mathrm{z}$ ponoszeniem znacznych nakładów finansowych, o czym mowa $\mathrm{w}$ niniejszej pracy, której zasadniczym celem jest próba przedstawienia ponoszonych przez wytwórcę kosztów implementacji nowego wyrobu jako bariery innowacji produktowych ${ }^{4}$. Osiągnięcie tak postawionego celu jest możliwe poprzez analizę wybranego przypadku implementacji, który potwierdza, że związane z nią koszty wskutek niewielkiej serii produkcji - mogą implikować sytuację, w której następuje ograniczenie zysku lub nawet strata; w perspektywie krótkoterminowej stanowi to przesłankę o jej zaniechaniu. W ramach badań uzyskano odpowiedź na pytanie: czy ilość implementowanych przez wytwórcę wyrobów jest pochodną - posiadanych przez niego - zdolności technologicznych odzwierciedlonych w możliwości pozyskania i wykorzystania nowej technologii wytwarzania?

Ilekroć mowa o nowej technologii wytwarzania, autorzy mają na myśli zmianę technologii (sposobu przetworzenia surowca w produkt) obejmującą treść (parametry) i kolejność przebiegu operacji składających się na dany proces technologicz-

${ }^{4}$ Koszty - jako najważniejsze pozycje - szczegółowo prezentuje rachunek zysków i strat wskazany w dyrektywie Parlamentu Europejskiego i Rady, dotyczący mikrojednostek według regulacji sprawozdawczości finansowej [Nowak 2015a, s. 1012]. 
ny ${ }^{5}$. Prowadzą do stworzenia nowych technologii odzwierciedlonych w możliwościach implementowania nowych produktów zaspokajających nowe potrzeby klienta (okazje) lub dotychczasowe (znane) potrzeby w nowy (bardziej efektywny) sposób, a których implementacja jest możliwa dzięki zdolności do jej rekonfigurowania [Amin (red.) 1994; Autio 1997; Carnabuci, Bruggeman 2009; Hirst, Zeitlin 2006; Zakrzewska-Bielawska 2012; Eisenhardt, Martin 2000; Teece 2012, Christensen 1995; Garrouste, Saussier 2005; Wójcik-Karpacz 2013].

Niniejsze opracowanie ma na celu zapoznanie czytelnika z problematyką kosztów wynikających z realizacji procesów implementacyjnych. Istotne jest bowiem zapewnienie dostępu do informacji bieżących i strategicznych jako podstawy podejmowania decyzji ${ }^{6}$. Ze względu na typowe podejście do analizy kosztów tego obszaru zastosowano metodykę rachunku kosztów działań, bazującą na identyfikacji i rozliczaniu poszczególnych kosztów ponoszonych w ramach realizowanych procesów implementacyjnych, zwłaszcza że funkcja informacyjna ma nadrzędne znaczenie w rachunkowości [Kamela-Sowińska 2015, s. 143] zarówno finansowej, jak i zarządczej [Nita 2015, s. 286] 7 .

Rachunek kosztów znajduje potencjalne zastosowanie we wspomaganiu szeregu decyzji, zarówno operacyjnych, jak i strategicznych, dotyczących asortymentu, klientów, dostawców i procesów. Może dzięki temu stanowić pomocne narzędzie w procedurze wdrożeniowej, gdzie ocena efektywności i rentowności jest kluczowa dla poprawności i sukcesu usprawniania organizacji.

\section{Koszty implementacji jako bariera innowacji produktowych - rozważania systematyzujące}

Innowacje uznaje się współcześnie za podstawowy czynnik wzrostu i rozwoju organizacji; zdaniem wielu badaczy stanowią one klucz do osiągnięcia sukcesu na coraz bardziej konkurencyjnym rynku [Pichlak 2012, s. 9]. Sztuka systemowego wdrażania innowacji stanowi zatem cel, który umożliwia współczesnym organizacjom adaptowanie się do zmian zachodzących w ich otoczeniu. Innowacje są synonimem organizacji charakteryzujących się wysoką elastycznością wyrażającą się stopniem dopasowania do rynku. Innowacyjność oferty rynkowej - poprzez polepszenie po-

5 J. Schumpeter [1949, s. 68], R. Solow [1957, s. 312-320] już wiele lat temu zauważyli, że rozwój postępu technicznego, a w szczególności rozwój technologii i ich wdrożenie w procesach wytwórczych, stanowią istotną dźwignię konkurencyjności i siłę wiodącą wzrostu gospodarczego oraz rozwoju ekonomicznego.

6 Takie podejście jest zbieżne z ideą controllingu według podejścia metodycznego, rozumianego jako metoda zarządzania. Zagadnienie to porusza w swoich pracach M. Nowak [2007, 2008, 2013, 2015a].

7 W praktyce współczesnej rachunkowości dochodzi coraz częściej do przenikania się tych dwóch obszarów i występowania między nimi rozbieżności [Sobańska 2003; Taipaleenmäki, Ikäheimo 2013; Weißenberger, Angelkort 2011]. 
zycji konkurencyjnej - przyczynia się do wzrostu wartości przedsiębiorstwa. Staje się zatem kluczowym wyzwaniem dla współczesnych przedsiębiorstw, zwłaszcza na rynku dóbr przemysłowych [Korzeniowski, Ankiel-Homa, Czaja-Jagielska 2011, s. 9].

W kontekście poszukiwań nowych źródeł wartości przedsiębiorstwa coraz powszechniej uznaje się rosnącą rolę implementowanego produktu. W związku z tym istniejące w literaturze badania empiryczne objęły w szczególności analizy generowania i wdrażania innowacji produktowych. Na obecnym etapie rozwoju gospodarki rynkowej mamy bowiem sytuację, w której w celu zaspokojenia tych samych potrzeb wytwarzanych jest wiele różnych odmian produktów. Twierdzi się bowiem, że to właśnie odpowiednio dopasowany portfel produktów jest podstawą budowania względnie trwałej przewagi konkurencyjnej i podnoszenia wartości firmy8.

Konkurencyjność portfela produktowego pozostaje w ścisłym związku z mnogością czynników (zmiennych kontekstowych), które go kształtują, determinują jego zakres. W kontekście powyższego należy podkreślić, że nie jest zadaniem łatwym dokonanie pełnej identyfikacji różnorodnych czynników oraz kierunku i stopnia ich oddziaływania, zwłaszcza że uwarunkowania te z natury są dynamiczne (zmienne w czasie), a występujące między nimi relacje mają charakter sprzężeń zwrotnych; tym bardziej że rosnąca konkurencja oraz duża dynamika zmian w otoczeniu przedsiębiorstw, skutki globalnego kryzysu ekonomicznego, sprawiają, że wiele trady-

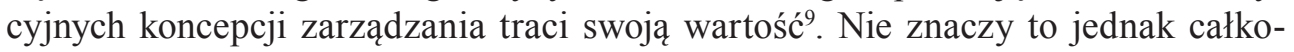
witej rezygnacji $\mathrm{z}$ dotychczasowego dorobku $\mathrm{w}$ tym zakresie. Wręcz przeciwnie. Konieczne jest wypracowanie mechanizmów kreowania zdolności przedsiębiorstw do przetrwania $w$ tych trudnych, niestabilnych czasach. Pojawia się zapotrzebowanie na niekonwencjonalne sposoby zarządzania, zwłaszcza że na rynku lawinowo wzrastają koszty surowców i pracy. Wobec tego wytwórcy stają przed dylematem: Co zrobić, aby nie obniżać zysku, a jednocześnie nie podnosić cen?

Przyjmując przesłanki kreowania niekonwencjonalnych, niekiedy lekko zmodyfikowanych - już istniejących - instrumentów zarządzania przedsiębiorstwem, na rynku dóbr przemysłowych, wydaje się zasadne zaproponowanie paradygmatu lidera kosztowego dążącego do osiągania wiodącej pozycji pod względem kosztów wytwarzania. Wiodąca pozycja kosztowa stwarza bowiem przedsiębiorstwu dużą swobodę strategiczną [Nowak 2015b, s. 133].

Jeżeli bowiem rynek kształtuje ceny i narzuca je producentom, najwyższą marżę uzyskują ci z nich, którzy implementują najtaniej.

Należy zaznaczyć, że w zarządzaniu firmą istotną rolę odgrywają koszty będące przedmiotem badań i oceny [Sawicki 2000, s. 9]. Zarządzanie kosztami obejmuje

8 W tym miejscu warto dodać, iż osiąganie przewagi konkurencyjnej uzależnione jest od rozwoju nowych produktów, a także wdrażania nowych technologii.

9 Podobny pogląd wyrażają I. Hejduk i W. Grudzewski [2011, s. 11], pisząc „Tradycyjne metody zarządzania kryzysowego nie dają już odpowiedzi, jak powinny sobie z kryzysem radzić przedsiębiorstwa". 
zbiór technik i metod służących kontroli oraz doskonaleniu działalności, procesów i produktów. Stosując to podejście, menedżerowie podejmują wysiłki ukierunkowane na optymalizację sposobu alokacji zasobów, poprawę efektywności zużycia zasobów przedsiębiorstwa oraz ich wykorzystanie w najbardziej rentownych segmentach działalności gospodarczej [Van Derbeck 2013, s. 2].

Poszukując optymalnej decyzji, wytwórca musi je brać pod uwagę, uznając je za jeden z podstawowych wskaźników ekonomicznych firmy, której podstawowym celem jest maksymalizacja dochodów, podnosząca wartość rynkową przedsiębiorstwa oraz umożliwiająca jej długotrwałą egzystencję i rozwój. W aktualnych uwarunkowaniach rynkowych zarząd i właściciele firmy, zamierzający zwiększyć ekonomiczną efektywność posiadanych zasobów i realizowanych procesów gospodarczych, powinni stosować nowoczesne metody i skuteczne sposoby zarządzania kosztami. Wymaga to z jednej strony ustalenia, czy dotychczasowa działalność przyniosła zamierzone efekty, z drugiej zaś - wskazania kierunków i sposobów doskonalenia działalności w bliższej i dalszej przyszłości.

Stały i szybki wzrost wartości przedsiębiorstwa - zdaniem autorów niniejszej pracy - jest domeną wytwórcy elastycznie dostosowującego się do ciągłych i nieprzewidywalnych zmian rynkowych. Realizowany jest z reguły przez przedsiębiorstwa działające w oparciu o rozwój wysokomarżowych - stanowiących nisze rynkowe - produktów, gwarantujących zysk, który jest pochodną wielkości dostawy, ceny sprzedaży oraz - związanych z implementacją - kosztów. Stopa zwrotu jest tym wyższa, im wyższa jest cena sprzedaży wyrobu i im niższe są koszty jego implementacji implikowane wielkością transakcji realizowaną wraz z pierwszą dostawą.

Istotnym elementem strategicznego zarządzania kosztami jest ustalenie długookresowych prawidłowości w kształtowaniu się kosztów oraz rozpoznanie sposobu i kierunku wpływu na ich poziom różnych czynników kosztotwórczych. Aby to było możliwe, należy stosować rachunek kosztów cyklu życia produktu, ujmujący koszty począwszy od fazy planowania produkcji i projektowania produktów, aż do wycofania produktów z rynku. Rachunek kosztów cyklu życia produktu powinien być uzupełniony o rachunek kosztów docelowych. Jest on bowiem nastawiony na pomiar kosztów we wczesnych fazach cyklu życia produktu i ukierunkowany na rynek oraz na klientów. Na etapie planowania produkcji i projektowania produktów przesądza się bowiem w $80 \%$ o przyszłych kosztach wytworzenia produktów. Ważnym czynnikiem kosztotwórczym o charakterze strategicznym jest zatem proces rozwoju produktu. Ze względu na silną orientację na rynek i klienta również klient powinien być uwzględniony $\mathrm{w}$ rachunku kosztów, a jego oczekiwania powinny stanowić punkt wyjścia do szacowania kosztów w długim okresie [Nowak 2015b, s. 140].

Przedmiotem zainteresowania wytwórcy powinny być koszty ponoszone na procesy i działania wykonywane w przedsiębiorstwie. Zarządzanie w układzie działań powinno umożliwić ocenę efektywności procesów implementacyjnych i stanowić przesłankę ich podjęcia lub - ze względu na długi okres zwrotu - zaniechania. 


\section{Różnicowanie portfela asortymentowego - strategia dyferencjacji produktowej ${ }^{10}$}

Efektywne wdrożenie nowego produktu jest celem każdego przedsiębiorstwa zorientowanego na podnoszenie swojej pozycji konkurencyjnej na rynku. Scentralizowanie działania firmy wokół nowych produktów, nowych procesów i zastosowania nowych materiałów to wciąż dla większości producentów kwestie priorytetowe. Pomimo że wprowadzenie nowego produktu na rynek jest najbardziej kosztochłonnym etapem $\mathrm{w}$ procesie rozwoju nowego produktu, a ponadto wiąże się $\mathrm{z}$ dużym ryzykiem i w pewnym stopniu zaburza normalną pracę przedsiębiorstwa (chociażby ze względu na włączenie nowego produktu w plany produkcyjne), jest działaniem koniecznym.

Tabela 1. Wyroby zdywersyfikowanego portfela asortymentowego - opis i charakterystyka

\begin{tabular}{|l|l|}
\hline \multicolumn{1}{|c|}{ Nazwa pola } & \multicolumn{1}{c|}{ Opis i charakterystyka wyrobu } \\
\hline Gwiazdy & $\begin{array}{l}\text { Charakteryzują się wysoką konkurencyjnością. Ich implementacja wymaga du- } \\
\text { żych nakładów finansowych, które jednak pokrywaja się wraz z pierwsza imple- } \\
\text { mentacja. W perspektywie uzyskuje się z nich znaczne przychody, gdyż tempo } \\
\text { wzrostu rynku jest dosyć wysokie. Produkt jest konkurencyjny i rozwojowy, } \\
\text { a inwestowanie w ,gwiazdę” daje dużą gwarancję zysków. Są najchętniej imito- } \\
\text { wane przez konkurencję, co w perspektywie może powodować spadek ich efek- } \\
\text { tywności implementacyjnej. }\end{array}$ \\
\hline Magnes & $\begin{array}{l}\text { Są to produkty nieprzynoszące znaczącej nadwyżki; strategicznie są rozwojo- } \\
\text { we. W perspektywie możliwy jest ich duży udział w rynku. W danym momencie } \\
\text { produkty te mają słabą efektywność implementacyjną - nie generują dodatnich } \\
\text { przepływów finansowych. W przypadku gdy dopełniają ofertę produkcyjną wy- } \\
\text { twórcy - czym przyciągają potencjalnych nabywców - nie należy wykluczyć ich } \\
\text { z programu produkcyjnego. }\end{array}$ \\
\hline Kluczowe nisze & $\begin{array}{l}\text { Są to produkty, które przynoszą firmie wysoką nadwyżkę; finansują implemen- } \\
\text { tację wraz z pierwszą dostawą. Ogólnie wzrost rynku jest stosunkowo niski; } \\
\text { w perspektywie długoterminowej dają duży udział w portfelu wyrobów wytwórcy } \\
\text { podejmującemu ryzyko ich implementacji; niskie zainteresowanie ze strony kon- } \\
\text { kurencji. Jest to kosztowy przywódca w danym segmencie, ale szanse na dalszą } \\
\text { ekspansję na rynek są małe. Implementowanie wyrobów tego rodzaju determino- } \\
\text { wane jest wysoką elastycznością wytwórcy. }\end{array}$ \\
\hline $\begin{array}{l}\text { Są to produkty deficytowe, trudno jest określić ich możliwości, które należy od- } \\
\text { nosić indywidualnie w kontekście danego wytwórcy. Cechują je wysokie koszty } \\
\text { implementacji. Mają względnie niski udział w rynku; stąd brak zainteresowania } \\
\text { ze strony konkurencji. Często charakteryzują się dużą dynamiką i w dłuższej per- } \\
\text { spektywie, jeśli zostaną odpowiednio ,doinwestowane”, mogą się stać „,klucza- } \\
\text { mi”. }\end{array}$ \\
\hline Dylematy
\end{tabular}

Źródło: opracowanie własne na podstawie [Nogalski, Niewiadomski, Szpitter 2016, s. 178].

${ }^{10}$ Różnicowanie portfela produktowego autorzy rozpatrują jako działanie słuszne, które maksymalizuje jakkolwiek rozumianą użyteczność (por. [Nowak 2015, s. 122]). Użyteczność rozumie się jako sumę użyteczności dla wszystkich, na których działanie wpływa [Goodin 2002, s. 287]. 
Rozwijają się wytwórcy, którzy współtworzą rzeczywistość, kreują oczekiwania oraz potrzeby klientów, zaspokajają je i myślą innowacyjnie w całym łańcuchu budowy wartości, zwłaszcza że jak zauważają K. Krzakiewicz i S. Cyfert [2013, s. 29], w nowych uwarunkowaniach trzeba się zajmować identyfikacją okazji w otoczeniu i kreowaniu innowacyjnych rozwiązań, pozwalających na wykorzystanie tychże okazji. Dobra innowacja produktowa zapewnia zatem sukces, tworzy wartość dodaną.

Efektem analizy portfela produktów powinno być ich zakwalifikowanie do którejś z kategorii: rozwojowych, nierozwojowych lub o zróżnicowanych możliwościach. Stwarza to szansę dokładnej oceny sytuacji konkurencyjnej przedsiębiorstwa i ocenę możliwości rozwojowych. Taka analiza stanowi ważny instrument planowania strategicznego. Dzięki temu przedsiębiorstwa mogą ustalić, z którymi produktami, towarami czy usługami mogą wiązać w przyszłości większe nadzieje na zbyt, a które z nich powinny być stopniowo wycofywane z ich portfela.

W aspekcie efektywności implementacyjnej przedsiębiorstwa - pod kątem dokładnej oceny portfela produktowego - autorzy dokonali pogrupowania składających się na niego potencjalnych wyrobów. Za wiodące przyjęto koszty implementacji oraz względne zapotrzebowanie rynkowe. Na podstawie przyjętych kryteriów ustalono, że każdy wyrób firmy można zakwalifikować do określonej grupy asortymentowej (tab. 1).

W kontekście tak dokonanego podziału autorzy postulują, że każda z kategorii powinna być - przynajmniej w jakiejś części - składową portfela produktowego wytwórcy, tzn. z żadnej z wymienionych kategorii produktów nie należy pochopnie rezygnować. Oczywiście kwestią bezsporną jest fakt, że należy dążyć do tego, aby udział produktów najwyżej pozycjonowanych z punktu widzenia konkurencyjności portfela produktowego stanowił możliwie największą jego część [Nogalski, Niewiadomski, Szpitter 2016, s. 178].

\section{Koszty implementacji jako bariera innowacji produktowych - analiza przypadku}

\subsection{Przedmiot, podmiot i metoda badań}

Aby rozpoznać badane zjawisko - nie zgłaszając przy tym ambicji do reprezentatywności [Czakon 2012, s. 210] - na rzecz realizacji celu niniejszego opracowania, autorzy posłużyli się szczególnym rodzajem badania jakościowego, tj. studium przypadku. Jako swoiste badania jakościowe zjawisk organizacyjnych studia przypadków są wprawdzie mniej przydatne do ustalenia związków przyczynowo-skutkowych, ale są użyteczne do znajdowania wartych wzięcia pod uwagę zmiennych wyjaśniających oraz zasugerowania mechanizmów, dzięki którym zmienne te wpływają na rezultat, czy też sformułowania pytań badawczych, które następnie zostaną ze względu na swoją wartość poddane dalszym analizom [Wójcik-Karpacz 
2009, s. 297]. Zasadność takiego podejścia zdaje się potwierdzać M. Lisiński, zauważając, że wiedza naukowa dotycząca każdej dyscypliny naukowej (w tym nauki o zarządzaniu), rozwija się nie tylko przez tworzenie i kształtowanie się nowych pojęć, twierdzeń czy teorii, lecz także przez zmiany w metodach rozwiązywania pojawiających się problemów. W związku z tym wykorzystanie z analizy przypad$\mathrm{ku}$ pozwoliło autorom na skonfrontowanie przyjętego przez nich rozumowania z postępowaniem rzeczywistych uczestników zdarzeń i procesów.

Inicjując badania, zaproszono przedsiębiorstwo produkcyjne działające w sektorze mechanizacji rolnictwa. Badania prowadzono przy współudziale właściciela firmy, kierownika produkcji oraz głównego technologa dzięki, którym uzyskano kluczowe - z punktu widzenia realizacji badań - informacje. Główny problem, przed którym stanął wytwórca, dotyczył zbyt wysokich kosztów, stanowiących barierę implementacji nowego wyrobu gotowego w postaci koła ślimakowego (ślimacznicy) o numerze referencyjnym 0200134640 (rys. 1) ${ }^{11}$.

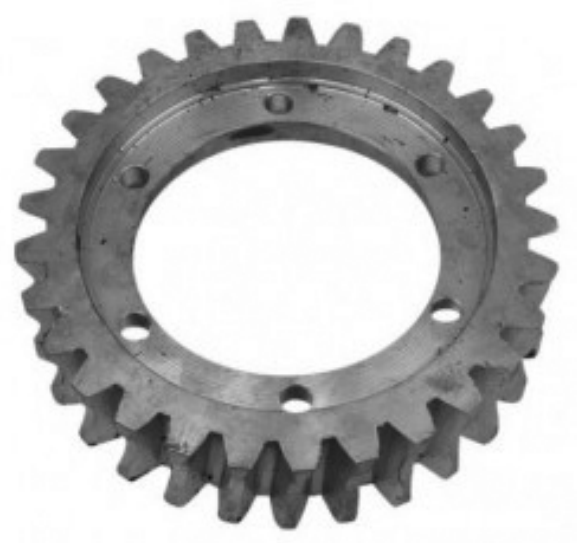

Rys. 1. Ślimacznica - przedmiot analizy

Źródło: materiały wewnętrzne firmy Fortschritt.

Badania, o których mowa w tej części opracowania, prowadzone z perspektywy celowo dobranego przedsiębiorstwa, dotyczą zaistniałego w praktyce przypadku ${ }^{12}$. Celem badań jest:

- próba zobrazowania ponoszonych przez wytwórcę kosztów implementacji nowego wyrobu jako bariery innowacji produktowych;

${ }^{11} \quad$ Stanowi podzespół przekładni ślimakowej wykorzystywanej do przenoszenia napędu taśmy przenośnika.

${ }^{12}$ Dobór przypadku poddanego ocenie był celowy, adekwatny do przyjętego w opracowaniu celu badań. 
- przedstawienie wdrażanych przez przedsiębiorstwo zmian technologicznych jako atrybutu sprzyjającemu minimalizacji kosztów implementacji wyrobu, co w perspektywie postrzegane jest jako zwrot ku większej elastyczności organizacji.

\subsection{Opis przypadku}

W ramach długookresowej współpracy z niemieckim dystrybutorem części zamiennych wytwórca, o którym mowa w pracy, otrzymał zapytanie ofertowe dotyczące możliwości zaimplementowania koła ślimakowego; zapytanie dotyczyło dostawy 200 sztuk wyrobu. Główny problem, przed którym stanął wytwórca, dotyczył zbyt wysokiej ceny, po jakiej może dostarczyć wymieniony wyrób, tj. 208,52 euro ${ }^{13}$. W wyniku dużej konkurencji wśród producentów części i podzespołów maszyn rolniczych pojawił się wytwórca, który zaoferował wyrób po znacznie niższej cenie, tj. 146 euro ${ }^{14}$. W związku z tym wytwórca musiał podjąć decyzję dotyczącą dostarczenia wyrobu w cenie zaoferowanej przez konkurencyjną firmę lub zaniechać jego implementacji ${ }^{15}$. W przypadku wyboru pierwszej możliwości wytwórca musiał liczyć się z tym, że przy obecnych kosztach produkcji koła jego dostawa po tak niskiej cenie będzie generowała znaczne starty. W przypadku wyboru drugiego wariantu istniało prawdopodobieństwo stopniowej utraty statusu kluczowego dostawcy części maszyn do nawożenia; wariant nie do przyjęcia, zwłaszcza że miniony rok dla branży maszyn i urządzeń rolniczych był najtrudniejszy od wielu lat. Spadki sprzedaży dotyczyły wszystkich grup produktowych. Już pod koniec 2015 roku zaobserwowano jej spadek. Te pesymistyczne oczekiwania pogłębiały się jeszcze w roku 2016; przy czym kryzys w branży dotyczy nie tylko Polski, ale też wszystkich czołowych rynków europejskich, w tym rynku niemieckiego. Utrzymująca się tendencja wpływa na bieżące decyzje w przedsiębiorstwach $\mathrm{z}$ sektora, które muszą walczyć o każdego klienta. Jak wynika z badań przeprowadzonych wśród członków Polskiej Izby Gospodarczej Maszyn i Urządzeń Rolniczych, spada odsetek firm, które deklarują skłonność do nowych inwestycji, skupiając się na dotychczas zrealizowanych ${ }^{16}$.

Konkurencja jest istotą wolnego rynku. Decydując się na prowadzenie działalności gospodarczej, wytwórca godzi się także na podjęcie walki o klienta z innymi graczami rynkowymi. W założeniu klient równa się zyskowi; przedsiębiorca podejmuje zatem wszelkie możliwe kroki, aby przyciągnąć do siebie kontrahenta, a dokładniej - jego kapitał. Świadomy mechanizmów rynkowych odbiorca wie, że

${ }^{13}$ Według tabeli kursów średnich Narodowego Banku Polskiego nr 028/A/NBP/2017 z dnia 9.02.2017 stanowi to 900,01 zł (1 euro $=4,3162$ zł). Zob. [www2].

14146 euro $=630,16 \mathrm{zł}$.

${ }^{15} \mathrm{~W}$ życiu bardzo często dochodzi do konfliktu między różnymi wariantami, z których każdy ma zasadniczo odmienny charakter [Nowak 2016, s. 462].

${ }^{16} \mathrm{O}$ ile w połowie 2014 roku, 70\% firm deklarowało, że planuje inwestycje, o tyle w sierpniu 2016 odsetek firm planujących inwestycje spadł do 37\%, za: [www3]. 
- wobec istnienia konkurencji - zmuszony jest pozyskiwać produkty po możliwie niskiej cenie.

Aby utrzymać dotychczasowego lub pozyskać nowego odbiorcę, tymczasowo wytwórca będzie zmuszony do stopniowej obniżki cen. Walka o klienta prowadzi niejednokrotnie do sytuacji niepożądanych, jak to miało miejsce w analizowanym przypadku.

Marża handlowa musi pokrywać typowe koszty prowadzenia działalności gospodarczej oraz zapewniać producentowi zysk gwarantujący optymalną rentowność alokowanego w ten sposób kapitału. Ustawa o zwalczaniu nieuczciwej konkurencji (Dz.U. z 1993, nr 47, poz. 211) wskazuje, że czynem nieuczciwej konkurencji jest sprzedaż towarów lub usług poniżej kosztów ich wytworzenia lub świadczenia albo ich odprzedaż poniżej kosztów zakupu w celu eliminacji innych przedsiębiorców. Niemniej jednak ocena, czy w danej sytuacji doszło do naruszenia przepisów, może być w praktyce bardzo trudna, o ile nie niemożliwa [www4]. Zawsze powstanie bowiem pytanie, czy sprzedaż w cenie 0,1 zł wyższej niż koszty produkcji, będzie wystarczającą marżą dla rentowności danego producenta, czy też dana marża powinna wynosić w określonej sytuacji np. 0,2 zł.

Ponadto trzeba zauważyć, że sprzedaż, o której mowa w np. 15 ust. 1 pkt 1 ZNK, polega na sprzedaży poniżej kosztów wytworzenia, ale nie poniżej cen rynkowych. Jeżeli zatem rynkowa cena koła wynosi 208,52 euro, a koszt jego wytworzenia przez danego wytwórcę wynosi np. 145 euro, wówczas sprzedaż po cenie 146 euro nie będzie, co do zasady, czynem nieuczciwej konkurencji. Jeżeli natomiast w podanym przykładzie producent będzie sprzedawał koło za 144 euro, wówczas czyn taki może zostać uznany za nieuczciwą konkurencję - cena będzie bowiem niższa od kosztów wytworzenia; ze względu na brak danych zakwestionowanie zaistniałej sytuacji jest w tym przypadku niemożliwe.

Prowadzone obserwacje wykazały, że do wykonywania podzespołów przeniesienia napędu maszyn bardzo często wykorzystuje się metodę, w wyniku której poprzez określone operacje technologiczne (np. obróbkę skrawaniem), kształt półfabrykatu uzyskuje się poprzez wykrawanie go z bryły. Technologia ta w procesie produkcji koła była do tej pory stosowana przez wytwórcę.

Ze względu na dobre własności wytrzymałościowe ${ }^{17}$, łatwość obróbki, wysoką odporność na ścieranie oraz temperaturę surowiec do produkcji koła stanowił brąz w gatunku B101 (rys. 2).

${ }^{17}$ Koło ślimakowe stanowi element przekładni, której zasada działania opiera się na współpracy naciętego ślimaka zazębionego z kołem ślimakowym. Podzespoły te podlegającej znacznym obciążeniom osiowym. 


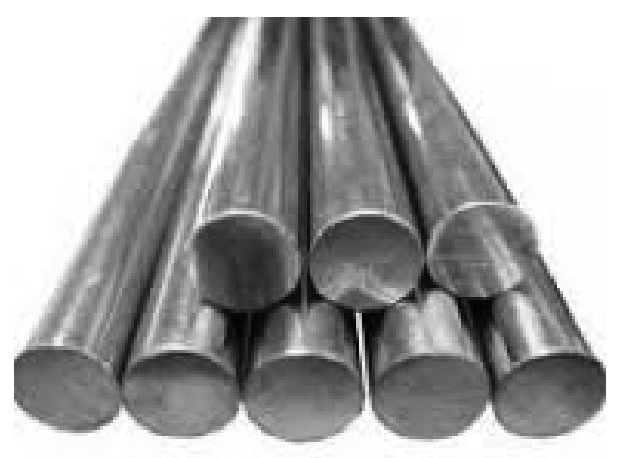

Rys. 2. Brąz - surowiec do produkcji koła

Źródło: materiały wewnętrzne firmy Fortschritt.

Biorąc pod uwagę wszelkie parametry dotyczące brązu B101 wykorzystywanego w procesie produkcji koła ślimacznicy, ustalono, że do jego wytworzenia niezbędny jest wałek o średnicy $210 \mathrm{~mm}$ i długości $55 \mathrm{~mm}$ (rys. 3).

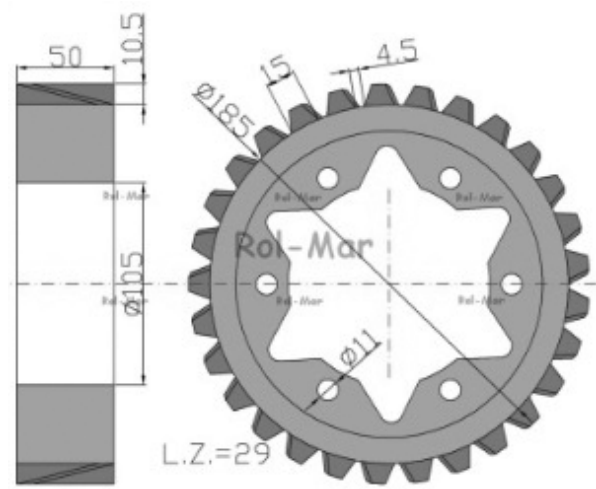

Rys. 3. Wymiary koła implikujące koszty implementacji

Źródło: materiały wewnętrzne firmy Fortschritt.

W ramach obliczeń przeprowadzonych za pomocą kalkulatora mas (rys. 4) ustalono wagę i koszt zakupu surowca przypadająca na jedną sztukę wyrobu, tj. 16,192 kg. Obliczono też, że na jego wytworzenie konieczny jest zakup surowca za łączną kwotę 728,64 zł. Uwzględniając koszty pracy ${ }^{18}$ oraz dostępną technologię wytwarzania, ostatecznie ustalono, że implementacja koła zamyka się w kwocie 794,60 zł.

${ }^{18}$ Koło ślimakowe jest kołem walcowym śrubowym o specjalnie ukształtowanym wieńcu, wymaga wielu specjalistycznych operacji technologicznych, co przekłada się na stosunkowo wysokie koszty pracy. 


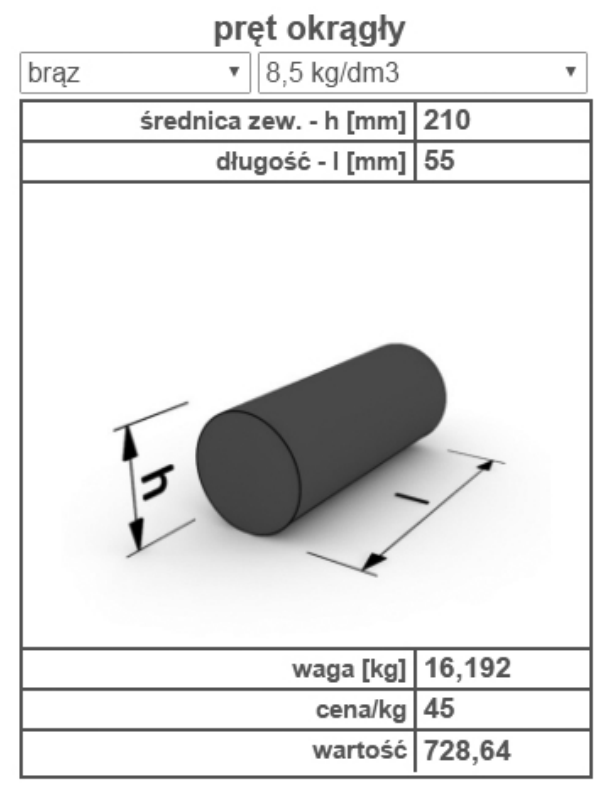

Rys. 4. Obliczanie masy surowca

Źródło: materiały wewnętrzne firmy Fortschritt.

Rozważając dostawę 200 sztuk wyrobu po cenie sprzedaży 630,16 zł (146 euro) ${ }^{19}$ i związane z tym koszty produkcji ${ }^{20}$, ustalono, że wytwórca ponosi stratę w wysokości $32888 \mathrm{z}^{21}$.

Sprzedaż koła w cenie 630,16 zł - pomimo że jest poniżej kwoty wytworzenia $794,60 \mathrm{zł}$ - według przywołanej ustawy nie była czynem nieuczciwej konkurencji. Wiadomo bowiem, że sama sprzedaż towarów poniżej kosztów wytworzenia nie stanowi jeszcze czynu nieuczciwej konkurencji, o którym mowa w cytowanym przepisie. Stosowanie takich cen musi być przede wszystkim podjęte w celu eliminacji innych przedsiębiorców, co według autorów jest stosunkowo trudne do udowodnienia. Jeżeli przedsiębiorca działa w celu wejścia na rynek czy też promocji nowego asortymentu - tak jak miało to miejsce w omawianym przypadku - to powyższy przepis ustawy o zwalczaniu nieuczciwej konkurencji nie będzie miał zastosowania. Aby zakwestionować stosowanie takiej polityki cenowej, trzeba by wykazać jeszcze inne przesłanki, co jest praktycznie niemożliwe. Ponadto proponowana przez konkurenta niższa cena nie zawsze musi oznaczać, że sprzedaje on poniżej kosztów wytworzenia.

\footnotetext{
${ }^{19} 630,16 \mathrm{zł} \times 200 \mathrm{szt} .=126032 \mathrm{zł}$.

${ }^{20}$ Uwzględniając koszty zakupu surowca $-728,64$ zł oraz koszty pracy $-65,96$ zł.

${ }^{21}$ Suma poniesionych kosztów wynosi 158920 zł, w tym: koszty pracy - 13192 zł; koszty surowca -145728 zł.
} 
Niezależnie od wszystkiego - uwzględniając powyższą kalkulację - implementacja w ramach przedstawionej konfiguracji byłaby całkowicie nieracjonalna, wbrew zasadom ekonomii. $Z$ drugiej strony producent świadomy jest faktu, że pozyskanie nowego odbiorcy kosztuje kilkakrotnie więcej niż rozszerzanie współpracy z obecnym partnerem; wymaga czasu i wiąże się z dużym ryzykiem ${ }^{22}$. To sprawia, że funkcjonowanie firm musi ulec przewartościowaniu, tym bardziej że odnoszenie sukcesów na rynku wymaga zupełnie nowych reguł. Zaufanie do partnera okazuje się obecnie ważniejsze niż nastawienie wyłącznie na sprzedaż. Tworzenie przyjaznych więzi pomiędzy dostawcami a odbiorcami staje się nieodzowną wartością firmy, a wypracowane zaufanie jest pochodną sukcesu. W związku z tym, ze względu na wiążące partnerów zaufanie i długotrwałe relacje, zaczęto poszukiwać rozwiązania, w ramach którego - przy z góry narzuconej cenie sprzedaży - implementacja koła mogłaby zapewnić zakładaną przez wytwórcę efektywność; pokonywanie bariery w postaci zbyt wysokich kosztów produkcji.

Prowadzone obserwacje wykazały, że do wykonania koła ślimakowego można wykorzystać dwie metody. Pierwszą z nich jest obróbka skrawaniem, gdzie kształt półfabrykatu uzyskuje się poprzez wykrawanie go z bryły (technologia dotychczas stosowana przez wytwórcę). Druga metoda polega na odlewaniu półfabrykatu, który następnie poddawany jest obróbce ubytkowej i wykańczającej. Każda z tych metod ma swoje wady i zalety. Istotny jest wybór bardziej ekonomicznej. W związku z tym - w celu dokładnego oszacowania i porównania kosztów implementacji dla każdej z metod - w dalszej części pracy przedstawiono proces produkcji koła według wariantu drugiego.

\section{Zmiana technologii wytwarzania jako metoda minimalizacji kosztów implementacji - likwidacja bariery}

Metoda implementacji koła ślimakowego - według wariantu drugiego - ma znamiona produkcji „odchudzonej”. Zużywając mniej zasobów - mniej ludzkiego wysiłku, mniej urządzeń, mniej czasu i pieniędzy - wytwórca spełnia oczekiwania klienta dokładnie w sposób, jakiego on oczekuje. Zmiana technologii produkcji implikująca stopień wykorzystania - zoptymalizowanego pod względem ceny zakupu - surowca wpływa na obniżenie kosztów wytworzenia wyrobu gotowego; przełamuje barierę implementacji. Stosując alternatywną technologię, w wyniku procesu odlewania uzyskuje się półfabrykaty, które po usunięciu stosunkowo niewielkich naddatków technologicznych mogą uzyskać ten sam kształt jak w przypadku wytaczania ich z pełnej bryły.

${ }^{22}$ Im wyższe koszty zmiany dostawcy, odczuwane ryzyko czy większe znaczenie nabywanego dobra lub usługi z punktu widzenia działalności nabywcy, tym rodzi się większy poziom uzależnienia odbiorcy od źródła zakupu. Istotnym wyznacznikiem skłonności nabywców do rozwijania relacji długookresowych jest rodzaj nabywanego produktu, co wynika ze struktury branżowej rynków przemysłowych [Nogalski, Niewiadomski 2017]. 
Podstawą do opracowania technologii odlewania danego półfabrykatu był jego kształt, wymiar i stopień skomplikowania oraz materiał, z którego ma być wykonany $^{23}$. W pierwszej kolejności - uwzględniając niezbędne naddatki technologiczne oraz pochylenia - na podstawie przygotowanej dokumentacji wykonano komputerowy model $3 \mathrm{D}^{24}$. Powyższe działania pozwoliły na oszacowanie kosztu uzyskania odlewów przeznaczonych do dalszej obróbki ${ }^{25}$. Biorąc pod rozwagę różne warianty i uwzględniając koszty implementacji, do wykonania odlewu koła ślimakowego wybrano technologię formy piaskoweje ${ }^{26}$. Powyższe działania stanowiły podstawę dalszych analiz, a mianowicie pozwoliły na precyzyjne ustalenie kosztu wykonania modelu odlewniczego, co w perspektywie miało olbrzymie przełożenie na dochodowość omawianej - według tego wariantu - implementacji. Oszacowano, iż koszt jego produkcji kształtuje się na poziomie $5500 \mathrm{zł}$.

Wziąwszy to pod uwagę, w celu określenia, czy proponowana zmiana technologii wytwarzania wpłynie na całkowite koszty produkcji koła ślimakowego, za zasadne uznano przeprowadzenie analizy procesu produkcji koła w ramach przedstawionego wariantu.

W wyniku zastosowania omawianej technologii wytwarzania, wytwórca uzyskał znaczną oszczędność; licząc na jedna sztukę koła, tj. 376,70 zł. Uwzględniając koszty zakupu surowca (odlewu wykonanego z brązu) - 350 zł, koszty pracy $40,40 \mathrm{zl}$ (w tym: toczenie $-4,50 \mathrm{zl}$, frezowanie $-35 \mathrm{zl}$, wiercenie $-0,90 \mathrm{zl}$ ) oraz dodatkowe koszty implementacji - związane z wykonaniem modelu odlewniczego w wysokości 27,50 zł, koszty produkcji koła ślimacznicy w ramach wariantu drugiego oscylują na poziomie 417,90 zł. Suma kosztów poniesionych na implementację 200 sztuk koła ślimakowego wynosi 83580 zł; w tym: jednorazowe koszty oprzyrządowania i modelu -5500 zł; koszty surowca -70000 zł (200 szt. $\times 350$ zł), koszty pracy $-8080 \mathrm{zł}(200 \mathrm{szt}$. $\times 40,40 \mathrm{zl})$.

Rozważając dostawę 200 sztuk koła w cenie sprzedaży 630,16 zł - w ramach omawianej technologii wytwarzania - wytwórca osiąga zysk w wysokości 42452 zł. Okazało się, że dzięki wprowadzonej innowacji technologicznej ponoszone przez wytwórcę koszty implementacji nowego wyrobu nie stanowiły bariery innowacji produktowych.

$\mathrm{Na}$ gruncie analizy literaturowej oraz w wyniku prowadzonej dyskusji dostrzega się zależność pomiędzy innowacyjnością technologiczną a innowacyjnością pro-

${ }^{23} \mathrm{~W}$ omawianym przypadku materiał stanowił brąz.

${ }^{24}$ Dokumentacja posłużyła do opracowania technologii wykonania formy odlewniczej.

${ }^{25}$ Prace prowadzono przy współudziale jednej z odlewni matali kolorowych.

${ }^{26} \mathrm{~W}$ ramach jej przygotowania wyróżniono następujące etapy: a) opracowanie trójwymiarowej technologii odlewniczej przy zastosowaniu wspomagania komputerowego (edytory graficzne, symulacje komputerowe), b) opracowanie modeli wirtualnych i dokumentacji oprzyrządowania odlewniczego, c) wykonanie modeli odlewniczych (płyta modelowa lub klasyczny model odlewniczy), d) wykonanie form na podstawie modeli odlewniczych, e) wytop dobranego stopu odlewniczego, e) zalewanie form, studzenie i wybicie form odlewniczych, oczyszczanie odlewów, odcięcie układów wlewowych i zasilających. 
duktową. Zależność ta przejawia się w strategicznym uwarunkowaniu działalności organizacji względem zachodzących w niej zmian [Pichlak 2012, s. 34]. Innowacyjność technologiczna stanowi podstawę uzyskania przewagi konkurencyjnej na rynku i coraz częściej postrzegana jest jako - skoncentrowana na permanentnym i świadomym poszukiwaniu nowych idei, pomysłów, wynalazków, sposobów postępowania, analizowaniu badań naukowych, opracowań teoretycznych - strategia długoterminowa przełamująca barierę implementacyjną.

\section{Zakończenie}

Nowoczesny proces podejmowania decyzji wymaga opracowania metod dokonywania obiektywnych rozstrzygnięć na podstawie wyników analizy wiarygodnych informacji [Nowak 1994, s. 9]. Opracowuje się warianty rozwiązania problemu, a następnie przyjmuje wariant optymalny. Decydent musi mieć możliwość wyboru jednego z wielu potencjalnych rozwiązań. Konieczne jest też określenie kryterium determinującego ów wybór; jako że koszty to podstawowy czynnik decydujący o wzroście efektywności, stanowiły one przesłankę ów wybór determinującą [Nowak, Wierzbiński 2015, s. 13].

W pracy przedstawiono ponoszone przez wytwórcę koszty implementacji nowego wyrobu, tj. koła ślimakowego, będące barierą innowacji produktowych. Było to możliwe dzięki szczegółowej analizie wybranego przypadku ${ }^{27}$. Potwierdzono, że związane z implementacją koszty - wskutek niewielkiej serii produkcji - mogą implikować sytuację, w której następuje ograniczenie zysku lub nawet strata; w perspektywie krótkoterminowej w wielu przypadkach stanowi to przesłankę o zaniechaniu implementacji. W ramach badań potwierdzono, że ilość implementowanych przez wytwórcę wyrobów jest pochodną posiadanych przez niego ust. 1 pkt 1 [Ustawa z dnia 16 kwietnia 1993] zdolności technologicznych, odzwierciedlonych w możliwości pozyskiwania i wykorzystywania innowacji w zakresie technologii wytwarzania.

\section{Literatura}

Amin A. (red.), 1994, Post-Fordism. A Reader, Blackwell Publishers, Oxford, Malden.

Autio E., 1997, New technology - based firms in innovation networks symplectic and generative impacts, Research Policy, vol. 26, s. 263-281.

Carnabuci J., Bruggeman J., 2009, Knowledge specialization, knowledge brokerage and the uneven growth of technology domains, Social Forces, vol. 88, no. 2, s. 607-641.

Christensen J.F., 1995, Asset profiles for technological innovation, Research Policy, vol. 24, s. 727-745.

${ }^{27}$ Prowadzona w pracy analiza polegała na rozłożeniu danej całości na jej elementy składowe i badaniu każdego z nich z osobna. Analizę jako metodę postępowania naukowego szeroko rozpatruje w swojej pracy E. Nowak [1996 (red.), s. 10]. 
Czakon W., 2012, Sieci w zarządzaniu strategicznym, Oficyna Wydawnicza Wolters Kluwer business, Warszawa.

Eisenhardt K. M., Martin J.A.M., 2000, Dynamic capabilities: What are they?, Strategic Management Journal, vol. 21, no. 10/11, s. 1105-1121.

Garrouste P., Saussier S., 2005, Looking for a theory of the firm: Future challenges, Journal of Economics Behavior \& Organization, vol. 58, s. 178-199.

Goodin R.E., 2002, Użyteczność i dobro, [w:] Singer P. (red.), Przewodnik po etyce, Książka i Wiedza, Warszawa.

Hejduk I., Grudzewski W., 2011, Sustainable enterprises (przedsiębiorstwo przyszłości) - odpowiedzia na kryzys ekonomiczny, [w:] Hejduk I. (red.), Sustainability odpowiedzia na kryzys ekonomiczny. Nowe koncepcje przedsiębiorstwa przyszłości, ORGMASZ, Warszawa.

Hirst P., Zeitlin J., 2006, Flexible Specialization versus Post-Fordism: Theory, Evidence and Policy Implications, [w:] Beynon H., Nichols T. (red.), The Fordism of Ford and Modern Management, Elgar, Cheltenham.

Kamela-Sowińska A., 2015, Obrót gospodarczy jako dobro prawnie chronione przez ustawę o rachunkowości. Rachunkowość - polityka makroekonomiczna-globalizacja, Prace Naukowe Uniwersytetu Ekonomicznego we Wrocławiu, nr 390, s. 142-149.

Korzeniowski A., Ankiel-Homa M., Czaja-Jagielska N., 2011, Innowacje w opakowalnictwie, Wydawnictwo Uniwersytetu Ekonomicznego w Poznaniu, Poznań.

Krzakiewicz K., Cyfert S., 2013, Role przywódców w procesie zarządzania innowacjom. Innowacje w zarzadzaniu, Prace Naukowe Uniwersytetu Ekonomicznego we Wrocławiu, nr 300.

Nita B., 2015, Sprawozdawczość segmentowa jako przejaw konwergencji rachunkowości finansowej i rachunkowości zarzadczej. Teoria rachunkowości, sprawozdawczość i analiza finansowa, Prace Naukowe Uniwersytetu Ekonomicznego we Wrocławiu, nr 388, s. 285-294.

Nogalski B., Niewiadomski P., Szpitter A., 2016, Koncepcja metody pomiaru konkurencyjności portfela produktowego elastycznej organizacji, [w:] Osbert-Pociecha G., Nowosielski S. (red.), Meandry teorii i praktyki zarządzania, Wydawnictwo Uniwersytetu Ekonomicznego we Wrocławiu, Wrocław, s. 174-189.

Nowak E., 1994, Decyzyjne rachunki kosztów, Wydawnictwo Naukowe PWN, Warszawa.

Nowak E., 2015a, Sprawozdawczość finansowa mikrojednostek w świetle regulacji rachunkowości, Zeszyty Naukowe Uniwersytetu Szczecińskiego, nr 854, Finanse, Rynki Finansowe, Ubezpieczenia, nr 73, s. 1007-1015.

Nowak E., 2015b, Zarzadzanie kosztami zorientowane na strategię przedsiębiorstwa, Studia Ekonomiczne. Zeszyty Naukowe Uniwersytetu Ekonomicznego w Katowicach, nr 229, s. 133-142.

Nowak E. (red.), 1996, Leksykon rachunkowości, Wydawnictwo Naukowe PWN, Warszawa.

Nowak E., Wierzbiński M., 2015, Rachunek kosztów. Modele i zastosowania, PWE, Warszawa.

Nowak M., 2007, Rachunkowość, controlling, zarzadzanie. Rozważania o relacjach, [w:] Nowak E. (red.), Paradygmaty rachunkowości, Wydawnictwo Akademii Ekonomicznej we Wrocławiu, Wrocław.

Nowak M., 2008, Controllingowe wsparcie usprawnienia pracy menedżera oraz optymalizacji jej efektów, Problemy Zarządzania, nr 4, s. 89-102.

Nowak M., 2013, Controlling w zarzadzaniu. Uwarunkowania psychologiczne, Wydawnictwo Uniwersytetu Ekonomicznego we Wrocławiu, Wrocław.

Nowak M., 2015, Etyka controllingowego pomiaru dokonań w świetle filozofii utylitarystycznej-zarys koncepcji, Zeszyty Teoretyczne Rachunkowości, t. 82(138), s. 113-128.

Nowak M., 2016, Konflikt etyczny w pracy księgowego i biegłego rewidenta. Pomiędzy moralnościa ogólna, moralnościa roli a interesem własnym, Prace Naukowe Uniwersytetu Ekonomicznego we Wrocławiu, nr 440, s. 461-470.

Pawlak J., 2013, Struktura własnościowa środków mechanizacji rolnictwa w Polsce w latach 1990-2010, Roczniki Ekonomii Rolnictwa i Rozwoju Obszarów Wiejskich, t. 100, z. 1, s. 89-101. 
Pichlak M., 2013, Uwarunkowania innowacyjności organizacji, Studia teoretyczne i wyniki badań empirycznych, Difin, Warszawa.

Sawicki K., 2000, Analiza kosztów firmy, PWE, Warszawa.

Schumpeter J.A., 1949, The Theory of Economic Development, Harvard University Press, Cambridge, Massachusetts.

Sobańska I., 2003, Wpływ MSR na integrację rachunkowości: rachunkowość finansowa i rachunkowość zarzadcza, Zeszyty Teoretyczne Rachunkowości, t. 13(69).

Solow R.M., 1957, Technical change and the aggregate production function, Review of Economics and Statistics, vol. 39, s. 312-320.

Taipaleenmäki J., Ikäheimo S., 2013, On the convergence of management accounting and financial accounting - the role of information technology in accounting change, International Journal of Accounting Information Systems, vol. 14 (4).

Teece D.J., 2012, Dynamic capabilities: Routines versus entrepreneurial action, Journal of Management Studies, vol. 49, issue 8.

Ustawa z dnia 16 kwietnia 1993 r. o zwalczaniu nieuczciwej konkurencji, Dz.U. z 1993, nr 47, poz. 211.

Van Derbeck E.J., 2013, Principles of Cost Accounting, South-Western Cengage Learning, Mason.

Weißenberger B.E., Angelkort H., 2011, Integration of financial and management accounting systems: The mediating influence of a consistent financial language on controllership effectiveness, Management Accounting Research, vol. 22 (3).

Wójcik-Karpacz A., 2009, Wspótpraca międzynarodowa przedsiębiorstwa produkcyjnego z zagranicznym partnerem gospodarczym - case research, Studia i Materiały. Miscellanea Oeconomica, R. 13, nr 1 .

Wójcik-Karpacz A., 2013, Zdolności dynamiczne jako przedmiot eksploracji naukowej zarzadzania strategicznego, [w:] Krupski R. (red.), Zarządzanie strategiczne. Quo vadis?, Prace Naukowe Wałbrzyskiej Wyższej Szkoły Zarządzania i Przedsiębiorczości w Wałbrzychu, t. 22, nr 2.

Zakrzewska-Bielawska A., 2012, Zarzqdzanie strategiczne w przedsiębiorstwach wysokich technologii, [w:] Werewka J. (red.), Zarzadzanie projektami w przedsiębiorstwie informatycznym. Metodologia i strategia zarządzania, Wydawnictwo AGH, Kraków, s. 87-116.

[www1] http://szkolaletnia.ue.wroc.pl/index.php/tematyka/(26.04.2017).

[www2] http://www.nbp.pl/home.aspx?navid=archa\&c=/ascx/tabarch.ascx\&n=a028z170209 (26.02.2017).

[www3] http://www.farmer.pl/technika-rolnicza/pigmiur-dla-branzy-maszynowej-to-byl-najtrudniejszy-rok-od-wielu-lat,68727,1.html (26.02.2017).

[www4] http://www.paiz.gov.pl/prawo/prawo_konkurencji/artykuly/wymogi_minimalnego_zysku. (26.02.2017). 